Article

\title{
The Effect on Tytanit Foliar Application on the Yield and Nutritional Value of Festulolium braunii
}

\author{
Elżbieta Malinowska *(D), Kazimierz Jankowski, Paweł Kania and Martyna Gałecka
}

Faculty of Agrobioengineering and Animal Husbandry, Siedlce University of Natural Sciences and Humanities, Prusa 14, 08-110 Siedlce, Poland; kazimierz.jankowski@uph.edu.pl (K.J.); pawelkania933@gmail.com (P.K.); nati11x@wp.pl (M.G.)

* Correspondence: elzbieta.malinowska@uph.edu.pl; Tel.: +48-25-6431319

Received: 14 May 2020; Accepted: 11 June 2020; Published: 14 June 2020

\begin{abstract}
The aim of the research was to assess the content of protein and soluble sugars and the yield of Festulolium braunii treated with different fertilizers. The effects of Tytanit foliar application at a concentration of $0.2 \%$ and $1 \%$ and of mineral nitrogen at a dose of 80 and $160 \mathrm{~kg} / \mathrm{ha}$ were studied in the experiment. When the grass was fully developed (2015-2017), Festulolium braunii was harvested three times a year. Mineral nitrogen fertilizer in combination with Tytanit increased the yield and the concentration of proteinin the plants. Each year the highest yield was recorded on plots treated with mineral nitrogen at a dose of $160 \mathrm{~kg} \mathrm{ha}^{-1}$ in combination with the foliar application of Tytanit at a concentration of $1 \%$. In the 1 st and 2 nd years of the research, Festulolium braunii treated with one dose of Tytanit at a concentration of $1 \%$ contained more soluble sugars than plants from plots treated with nitrogen.
\end{abstract}

Keywords: Festulolium braunii; yield; protein content; soluble sugars

\section{Introduction}

Progressive climate change is not conducive to the growth and development of forage grass species. However, thanks to hybrids, it is possible to produce forage effectively even under such stress conditions like drought, which is increasingly occurring now. In recent years, there has been an increase in interest in cross-genus and cross-species hybrids within the Lolium-Festuca complex. Combining many complementary characteristics of these grasses into one genome brings many benefits to agricultural practice [1-3]. Festulolium produces a high biomass yield and is resistant to cold and drought [4-8]. Borowiecki [5] reports that in terms of protein content and the amount of energy, Festulolium braunii exceeds Skra, a standard variety of Poa pratensis L., and is more resistant to cold than Italian ryegrass L. var. Lotus. Festulolium braunii varieties belong to grasses with high yield potential, especially in the first year and with appropriate fertilizer treatment [9]. The application of mineral nitrogen to grassland should be differentiated according to its botanical composition and the type of soil. The nitrogen dose should be adapted to the way meadows and pastures are managed, more specifically to the frequency of mowing or grazing. Too much mineral nitrogen can decrease forage quality [10]. In recent years, particular attention has been paid to the possibility of using growth regulators and amendments that could replace or supplement nitrogen fertilizer in increasing soil fertility [11-14]. The interest in such biological substances is mainly due to rising concern over the environment and food safety. The aim of the research was to assess the effects of Tytanit foliar application and different doses of mineral nitrogen on the yield and the content of protein and soluble sugars of Festulolium braunii. 


\section{Material and Methods}

The experiment was set up in the spring of 2014 in the field of the University of Natural Sciences and Humanities in Siedlce, in the Central-Eastern part of Poland, on soil with the granulometric composition of loamy sand, with $\mathrm{pH}_{\mathrm{KCl}}$ of 6.75 . Organic carbon content was $37.0 \mathrm{~g} \mathrm{~kg}^{-1}$ with $1.75 \mathrm{~g} \mathrm{~kg}^{-1}$ of total nitrogen. In contrast, available forms of phosphorus and potassium determined by the Egner-Rhiem method were within the moderate content of $39.9 \mathrm{mg} \mathrm{kg}^{-1}$ and $128 \mathrm{mg} \mathrm{kg}^{-1}$, respectively. The total content of the macronutrients in the soil was as follows $\left(\mathrm{g} \mathrm{kg}^{-1}\right)$ : $\mathrm{P}-1.05 ; \mathrm{K}-1.00 ; \mathrm{Ca}-2.40 ; \mathrm{Mg}-1.25$; S-0.508; Na-0.312. The Felopa variety of Festulolium braunii (K. Richt.) A. Camus was used in the experiment. The standard sowing rate was adopted according to the Institute of Land Reclamation and Grassland Farming in Falenty [15]. The area for the experiment was divided into plots of $1.5 \mathrm{~m}^{2}$. In the experiment, growth cycles (harvests) or years of research were the first test factor (A), while the second (B) was fertilizer treatment.

Each combination was replicated three times, in a completely randomized design:

- $\quad$ control (no treatment);

- $\quad$ ammonium nitrate $\left(\mathrm{N}_{1}\right) 80 \mathrm{~kg} \mathrm{~N} \mathrm{ha}^{-1},\left(24 \mathrm{~g} \mathrm{~N}_{\text {plot }}{ }^{-1}\right)$;

- $\quad$ ammonium nitrate $\left(\mathrm{N}_{2}\right) 160 \mathrm{~kg} \mathrm{~N} \mathrm{ha}^{-1},\left(47 \mathrm{~g} \mathrm{~N}_{\text { plot }}{ }^{-1}\right)$;

- Tytanit $\left(\mathrm{Ti}_{1}\right) 0.2 \%\left(1 \mathrm{~cm}^{3}\right.$ in $500 \mathrm{~cm}^{3}$ of water);

- $\quad$ Tytanit $\left(\mathrm{Ti}_{2}\right) 1 \%\left(5 \mathrm{~cm}^{3}\right.$ in $500 \mathrm{~cm}^{3}$ of water);

- ammonium nitrate $\left(\mathrm{N}_{1}\right)+$ Tytanit $\left(\mathrm{Ti}_{1}\right)$;

- $\quad$ ammonium nitrate $\left(\mathrm{N}_{2}\right)+$ Tytanit $\left(\mathrm{Ti}_{2}\right)$.

Each year mineral nitrogen was divided into three doses: the first applied in the early spring, before the start of the growing period, and the others after two subsequent harvests. Phosphorus-potassium fertilizers were not applied due to the moderate soil content of the available forms of those macronutrients. Tytanit spray was applied once during the stem formation stage.

Fertilizers were not used in the first year (2014) when the grass was planted. This period was treated as a preparatory time during which three cuttings were carried out to destroy the weeds. In the years of full use (2015-2017), Festulolium braunii $(\mathrm{Fb})$ was harvested three times. The first mowing was carried out in late May, the second in early July and the third in mid-September. The grass was cut at a height of 5-6 cm at the earing stage. Cutting at a height of less than $5 \mathrm{~cm}$ deprives the grass of lower leaves and stems containing spare substances necessary for plants to regenerate their organs. At the same time, the soil is too exposed. During the harvest, $0.5 \mathrm{~kg}$ of green matter was collected from each plot, in which air-dry matter content was determined. In the research, the yield of fresh and dry matter was measured by the oven-drying method. The collected material was dried at $105^{\circ} \mathrm{C}$ to constant mass in the drying oven SLN 32 produced by POL-EKO-APPARATURA. Subsequently, the plant samples were ground in the laboratory grinder Wż-1S, purchased at the Research Institute of the Bakery Industry in Bydgoszcz. In the dry plant material, the content of total protein and soluble sugars was determined with the NIRS method [PN-EN ISO 12099. 2013] using the NIRFlex N-500 apparatus with ready-made calibrations for roughage from the INGOT ${ }^{\circledR}$ company. These analyses were carried out at the Institute of Technology and Life Sciences in Falenty, which has the equipment and appropriate personnel for its operation.

The digestible protein content was calculated using the following formula [16]:

$$
\mathrm{BS}=0.946 * \mathrm{~N} * 6.25-3.52[\% \mathrm{DM}]
$$

The sugar-protein ratio of the plant dry matter was also calculated. Meteorological data for 2015-2017 were obtained from the Hydrological and Meteorological Station in Siedlce. In order to determine the temporary variability of temperatures and precipitation and their effect on the vegetation of the plants, Sielianinov's hydrothermal coefficient was calculated. It is based on the monthly amount 
of precipitation $(\mathrm{P})$ and the monthly sum of daily air temperatures $(\mathrm{t})$. Sielianinov's hydrothermal coefficient $(\mathrm{K})$ was calculated using the following formula [17]:

$$
\mathrm{K}=\mathrm{P} \times 10 / \Sigma \mathrm{t}
$$

K-Sielianinov's coefficient,

P-monthly sum of precipitation,

$\Sigma \mathrm{t}$-monthly sum of daily air temperatures.

The results of the research were processed statistically using a three-factor analysis of variance. The Fisher-Snedecor test was done to determine the significance of the effects of experimental factors on the parameters tested in the research. Tukey's test was used to compare means at the $\mathrm{LSD}_{0.05}$ significance level. All the calculations were carried out with the Statistica 10.0-2011 program [18].

\section{Results and Discussion}

In the first year of full use of Festulolium braunii (2015), optimal thermal and humidity conditions were only in April (Table 1). It was moderately wet in May, June, and August, while the remaining months were very dry and extremely dry. In the second year (2016), optimal conditions in terms of precipitation and air temperature were recorded in September. It was very humid in May, but June and August, the most important months for the proper growth and development of plants, were quite dry and extremely dry. In 2017, thermal and humidity conditions were even more unfavorable than in previous years. The beginning and end of the growing season were very humid and quite humid, while the period from May to August was quite dry and dry.

The statistical analysis of the research results (Table 2) indicated that there were significant variations in the biomass yield of Festulolium braunii across the growing seasons, depending on the experimental factors. In the first year of full use, the largest biomass yield $\left(9.80 \mathrm{tha}^{-1}\right)$ was on the plot with the mineral nitrogen dose of $160 \mathrm{~kg} \mathrm{ha}^{-1}\left(\mathrm{~N}_{2}\right)$, and when plants were treated with the combination of the above nitrogen dose and 1\% Tytanit; compared to control, the increase in the yield on these plots was $40 \%$. In the second and third years, an increase in the yield of Festulolium braunii on the plot with the highest dose of nitrogen supplemented with Tytanit was $54.5 \%$ and $75 \%$, respectively. Each year Tytanit doses increased the Festulolium braunii yield more than $80 \mathrm{~kg} \mathrm{ha}^{-1}$ nitrogen $\left(\mathrm{N}_{1}\right)$. As an average of all experimental plots, the largest yield $\left(8.60 \mathrm{t} \mathrm{ha}^{-1} \mathrm{DM}\right)$ was in the third year (2017) and the smallest (7.59 $\left.\mathrm{t} \mathrm{ha}^{-1} \mathrm{DM}\right)$ in the second (2016), while the yield average across all three years was $8.17 \mathrm{t} \mathrm{ha}^{-1} \mathrm{DM}$.

Fertilizer treatments, especially nitrogen, significantly increase the quantity and quality of grass yield, according to many authors [19-21], (nitrogen modifies the morphological and chemical properties of grasses, determining their yield and nutritional value. The higher dose of nitrogen applied with the higher concentration of Tytanit $\left(\mathrm{N}_{2}+\mathrm{Ti}_{2}\right)$ significantly increased the yield; the $9.92 \mathrm{tha}{ }^{-1} \mathrm{DM}$ yield from this plot, the average across three years, was the largest of all. Plants responded to mineral nitrogen treatment $\left(\mathrm{N}_{2}\right)$ with an average yield of $9.01 \mathrm{t} \mathrm{ha}{ }^{-1} \mathrm{DM}$. By contrast, Tytanit $\left(\mathrm{Ti}_{2}\right)$ foliar application increased the yield of Festulolium braunii to $8.66 \mathrm{t} \mathrm{ha}^{-1} \mathrm{DM}$. It was significantly higher than the yield of grass treated with nitrogen at a dose of $80 \mathrm{~kg} \mathrm{~N} \mathrm{ha}^{-1}\left(\mathrm{~N}_{1}\right)$ and higher than on the plot with the lower dose of nitrogen combined with $0.2 \%$ Tytanit $\left(\mathrm{N}_{1}+\mathrm{Ti}_{1}\right)$. The average yield on this plot was slightly lower than for grass treated with the standard nitrogen dose $\left(\mathrm{N}_{2}\right)$, and the differences were not statistically significant. It was observed that Tytanit single foliar application at a concentration of $1 \%$ affected the yield as much as the traditional mineral nitrogen fertilizer top dressing $\left(160 \mathrm{~kg} \mathrm{ha}^{-1}\right)$ applied in three split doses.

It was found that Festulolium braunii yields significantly varied across harvests, and different forms of fertilizer treatment affected differences between harvests (Figure 1). According to Staniak [22], the first harvest is essential for the forage production on arable land as it accounts for about $50 \%$ of the 
annual yield. In the present experiment, the first Festulolium braunii harvest was also much higher than the other two.

Table 1. Average daily air temperatures per month (OC), monthly rainfall (mm), and monthly Sielianinov's index.

\begin{tabular}{|c|c|c|c|c|c|c|c|c|}
\hline \multirow{3}{*}{ Year } & \multicolumn{8}{|c|}{ Month } \\
\hline & IV & $\mathbf{V}$ & VI & VII & VIII & IX & $x$ & Mean \\
\hline & \multicolumn{8}{|c|}{ Temperature } \\
\hline 2015 & 9.7 & 13.7 & 15.1 & 20.5 & 17.8 & 13.7 & 8.4 & 14.1 \\
\hline 2016 & 8.2 & 12.3 & 16.5 & 18.7 & 21.0 & 14.5 & 6.5 & 14.0 \\
\hline 2017 & 8.3 & 13.9 & 17.8 & 16.9 & 18.4 & 13.9 & 9.0 & 13.8 \\
\hline Mean & 8.3 & 13.3 & 16.5 & 18.7 & 19.1 & 14.0 & 8.0 & 13.9 \\
\hline Mean of 2004-2014 & 8.5 & 14.0 & 17.4 & 19.8 & 18.9 & 13.2 & 7.9 & 14.2 \\
\hline \multicolumn{9}{|c|}{ Rainfall (mm) } \\
\hline 2015 & 39.5 & 79.5 & 74.2 & 37.5 & 105.7 & 26.3 & 3.00 & 52.2 \\
\hline 2016 & 30.0 & 100.2 & 43.3 & 62.6 & 11.9 & 77.1 & 39.0 & 52.0 \\
\hline 2017 & 59.6 & 49.5 & 57.9 & 23.6 & 54.7 & 80.1 & 53.0 & 54.1 \\
\hline Mean & 43.0 & 76.4 & 58.5 & 41.2 & 57.4 & 61.2 & 31.7 & 52.8 \\
\hline Mean of 2004-2014 & 33.0 & 52.0 & 52.0 & 65.0 & 56.0 & 48.0 & 28.0 & 47.7 \\
\hline \multicolumn{9}{|c|}{ Sielianinov's coefficient (K) } \\
\hline 2015 & $1.36(\mathrm{o})$ & $1.87(\mathrm{mw})$ & $1.64(\mathrm{mw})$ & $0.59(\mathrm{sd})$ & $1.92(\mathrm{mw})$ & 0.64 (sd) & $0.12(\mathrm{ed})$ & - \\
\hline 2016 & $1.22(\mathrm{md})$ & $2.63(\mathrm{sw})$ & $0.87(\mathrm{~d})$ & $1.08(\mathrm{md})$ & $0.18(\mathrm{ed})$ & $1.46(\mathrm{o})$ & $1.94(\mathrm{mw})$ & - \\
\hline 2017 & $2.88(\mathrm{sw})$ & $1.15(\mathrm{md})$ & $1.08(\mathrm{md})$ & $0.45(\mathrm{sd})$ & $0.96(\mathrm{~d})$ & $1.92(\mathrm{mw})$ & $1.90(\mathrm{mw})$ & - \\
\hline
\end{tabular}

$\mathrm{K} \leq 0.4$ extreme drought (ed), $0.4<\mathrm{K} \leq 0.7$ severe drought (sd), $0.7<\mathrm{K} \leq 1.0$ drought (d), $1.0<\mathrm{K} \leq 1.3$ moderate drought (md), $1.3<\mathrm{K} \leq 1.6$ optimal (o), $1.6<\mathrm{K} \leq 2.0$ moderately wet (mw), $2.0<\mathrm{K} \leq 2.5$ wet (w), $2.5<\mathrm{K} \leq 3.0$ severely wet (sw), K > 3.0 extremely wet (ew).

Table 2. The yield of Festulolium braunii ( $\mathrm{t}$ ha $\left.{ }^{-1} \mathrm{DM}\right)$.

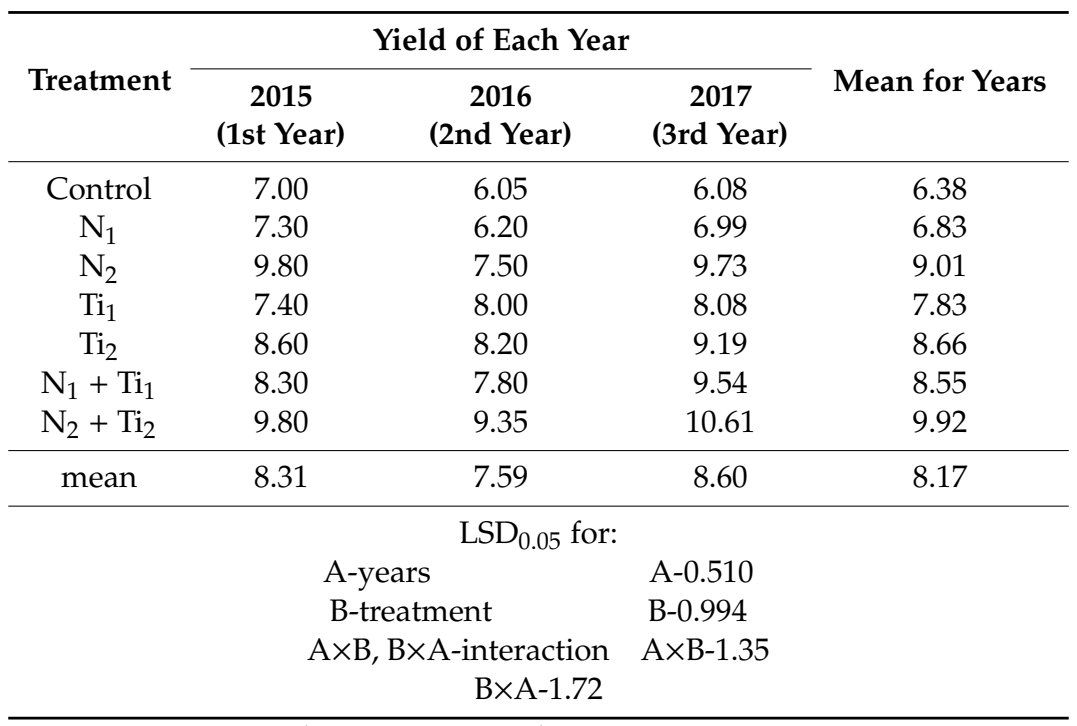

$\mathrm{N}_{1}-80 \mathrm{~kg} \mathrm{~N} \mathrm{ha}^{-1} ; \mathrm{N}_{2}-160 \mathrm{~kg} \mathrm{~N} \mathrm{ha}^{-1} ; \mathrm{Ti}_{1}-$ Tytanit $0.2 \% ; \mathrm{Ti}_{2}-$ Tytanit $1 \%$.

In conclusion, the largest Festulolium braunii yield, averaged across three years, was on the plot with the mineral nitrogen fertilizer dose of $160 \mathrm{~kg} \mathrm{ha}^{-1}\left(\mathrm{~N}_{2}\right)$ in combination with $1 \%\left(\mathrm{Ti}_{2}\right)$ of Tytanit applied to leaves. A comparable yield was recorded when grass was treated with the following three fertilizer treatments: (1) Tytanit at a concentration of 1\%; (2) nitrogen at a dose of $160 \mathrm{~kg} \mathrm{ha}^{-1}$; (3) nitrogen at a dose of $80 \mathrm{~kg} \mathrm{ha}^{-1}$ with Tytanit at a concentration of $0.2 \%$. The smallest biomass yield of Festulolium braunii was from the control plot. 


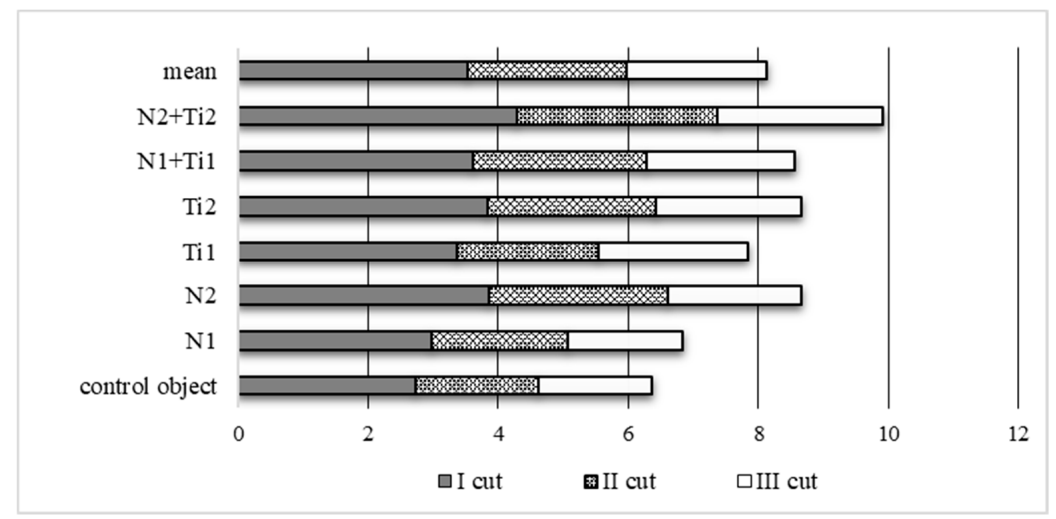

Figure 1. The yield of Festulolium braunii ( $\mathrm{t} \mathrm{ha}^{-1} \mathrm{DM}$ ) across harvest, a three-year average. $\mathrm{N}_{1}-80 \mathrm{~kg} \mathrm{~N}^{-1}$; $\mathrm{N}_{2}-160 \mathrm{~kg} \mathrm{~N} \mathrm{ha}^{-1}$; $\mathrm{Ti}_{1}-$ Tytanit $0.2 \%$; Ti 2 -Tytanit $1 \%$. LSD 0.05 for: A-0.492 (cuts); B-0.253 (treatment); A×B-ns; $\mathrm{B} \times \mathrm{A}-\mathrm{ns}$ (interaction).

Increasing the amount of mineral fertilizers applied to crops is only appropriate for farmers if it entails greater cost-effectiveness. It is most often assumed that mineral fertilizer treatment becomes profitable when the value of the yield is at least $50 \%$ higher than the costs incurred. The costs involved in the use of Tytanit in the experiment were much lower than the costs of nitrogen treatment. Tytanit is a catalyst for natural physiological processes in plants, positively affecting the quality and yields of crops [23,24]. It was used in the past only in the cultivation of vegetables and fruits [25]. However, in the experiment, it was proven that its foliar application was also very profitable in growing forage crops, as confirmed by the studies of Murawska et al., [26].

It was found that the experimental factors (fertilizer and harvest) significantly differentiated the content of total protein in the grass (Table 3). According to Brzóska [27], the minimum protein content in forage for dairy cows should be $150-170 \mathrm{~g} \mathrm{~kg}^{-1}$. Total protein content in Festulolium braunii ranged from $65.65 \mathrm{~g} \mathrm{~kg}^{-1}$ to $163.9 \mathrm{~g} \mathrm{~kg}^{-1} \mathrm{DM}$. Each year the highest protein content was recorded in grass treated with mineral nitrogen in combination with the foliar application of Tytanit. The smallest content was found in control plants. There were differences in the content of total protein between individual harvests. Its highest content was in the third cut and the smallest in the first. According to Ciepiela and Godlewska [28], the Kelpak biostimulant increased the protein content in Dg and Fb dry matter. Many authors [29-32] in their studies confirmed the effect of the grass harvest on the content of protein in dry matter.

The quantity and quality of protein are important in animal nutrition [33]. The content of digestible protein in control plants was $74.99 \mathrm{~g} \mathrm{~kg}^{-1}$, while in those treated with a higher dose of nitrogen and Tytanit $\left(\mathrm{N}_{2}+\mathrm{Ti}_{2}\right)$ it was $109.67 \mathrm{~g} \mathrm{~kg}^{-1}$ (Figure 2). Protein digestibility in fodder from all plots, except that of the control subject and the lower dose of $\mathrm{N}_{1}$, was usually above $90 \%$. Similar results were obtained by Grzelak [34] in hay from the Narew valley meadows. Spychała et al. [35] found that the digestibility of Camelina sativa marc protein was $88 \%$. In recent years, the decline in the population of ruminants has contributed to reducing the production of roughage, and the production of concentrated feed has increased. In Poland in the mid-1990s, in the overall production of protein, the share of protein from such feed was around $45 \%$, with $52-53 \%$ at the beginning of 2000 , and it recently increased to almost $58 \%$ [36].

It was found that the concentration of soluble sugars in the biomass of Festulolium braunii significantly varied depending on the treatment and harvest (Table 4). Each year, the combination of mineral nitrogen with Tytanit had a positive effect on the concentration of soluble sugars in the grass. Additionally, in the first and second years of the experiment, $1 \%$ Tytanit foliar application increased the content of soluble sugars compared to plants treated with mineral nitrogen. According to Ciepiela and Godlewska [28], the average concentration of soluble sugars in the biomass of Festulolium braunii was $122.9 \mathrm{~g} \mathrm{~kg}^{-1}$, with $104.1 \mathrm{~g} \mathrm{~kg}^{-1} \mathrm{DM}$ of protein. In the present experiment, the average content of soluble sugars in plants from all treatment combinations was $104.2 \mathrm{~g} \mathrm{~kg}^{-1}$ in the first year of the experiment 
and $99.06 \mathrm{~g} \mathrm{~kg}^{-1}$ in the third. The air temperature, which was too high, might have lowered sugar content in the grass. According to Grzelak [34] and Czyż et al. [37], the concentration of sugars in forage is dependent on the development stage of plants, air temperature, and many other factors. High temperatures increase the respiration of plants, and sugars are consumed in this process [38].

Table 3. Total protein content in Festulolium braunii ( $\left.\mathrm{g} \mathrm{kg}^{-1} \mathrm{DM}\right)$.

\begin{tabular}{|c|c|c|c|c|c|c|c|c|c|c|c|c|}
\hline \multirow{3}{*}{ Treatment } & \multicolumn{4}{|c|}{$\begin{array}{c}2015 \\
\text { (the 1st Year) }\end{array}$} & \multicolumn{4}{|c|}{$\begin{array}{c}2016 \\
\text { (the 2nd Year) }\end{array}$} & \multicolumn{4}{|c|}{$\begin{array}{c}2017 \\
\text { (the 3rd Year) }\end{array}$} \\
\hline & \multicolumn{4}{|c|}{ Cuts } & \multicolumn{4}{|c|}{ Cuts } & \multicolumn{4}{|c|}{ Cuts } \\
\hline & I & II & III & Mean & I & II & III & Mean & I & II & III & Mean \\
\hline Control & 71.57 & 73.40 & 74.18 & 73.05 & 76.32 & 85.37 & 84.71 & 82.13 & 65.65 & 114.5 & 101.3 & 93.82 \\
\hline $\mathrm{N}_{1}$ & 91.83 & 87.44 & 82.94 & 87.40 & 86.21 & 90.11 & 91.36 & 89.23 & 97.23 & 119.2 & 122.5 & 113.0 \\
\hline $\mathrm{N}_{2}$ & 99.83 & 108.7 & 127.3 & 111.9 & 88.01 & 95.23 & 96.23 & 93.16 & 92.20 & 129.4 & 132.9 & 118.2 \\
\hline $\mathrm{Ti}_{1}$ & 112.4 & 109.1 & 130.9 & 117.4 & 90.36 & 88.36 & 97.01 & 91.91 & 85.53 & 120.5 & 121.9 & 108.6 \\
\hline $\mathrm{Ti}_{2}$ & 111.7 & 116.1 & 115.4 & 114.4 & 87.12 & 89.36 & 90.23 & 88.90 & 86.39 & 125.4 & 106.9 & 106.2 \\
\hline $\mathrm{N}_{1}+\mathrm{Ti}_{1}$ & 124.3 & 125.0 & 142.6 & 130.7 & 90.23 & 95.12 & 100.2 & 95.18 & 84.69 & 162.7 & 158.6 & 135.3 \\
\hline $\mathrm{N}_{2}+\mathrm{Ti}_{2}$ & 109.7 & 114.8 & 133.4 & 119.3 & 100.2 & 99.67 & 112.3 & 104.06 & 112.7 & 130.2 & 163.9 & 135.6 \\
\hline mean & 103.1 & 104.9 & 115.3 & 107.7 & 88.35 & 91.89 & 96.01 & 92.08 & 88.92 & 128.8 & 129.7 & 115.8 \\
\hline \multicolumn{13}{|c|}{$\mathrm{LSD}_{0.05}$ for: } \\
\hline \multirow{2}{*}{\multicolumn{2}{|c|}{$\begin{array}{l}\text { A-cuts } \\
\text { B-treatment }\end{array}$}} & \multicolumn{3}{|c|}{ A-9.66 } & \multicolumn{4}{|c|}{ A-1.65 } & \multicolumn{4}{|c|}{ A-4.21 } \\
\hline & & \multirow{2}{*}{\multicolumn{3}{|c|}{$\begin{array}{c}\text { B-4.96 } \\
\mathrm{A} \times \mathrm{B}-13.12\end{array}$}} & \multirow{2}{*}{\multicolumn{4}{|c|}{$\begin{array}{c}\text { B-3.22 } \\
\mathrm{A} \times \mathrm{B}-4.37\end{array}$}} & \multicolumn{4}{|c|}{ B-8.20 } \\
\hline \multicolumn{2}{|c|}{$\begin{array}{l}\text { B-treatment } \\
\mathrm{A} \times \mathrm{B} \text {-interaction }\end{array}$} & & & & & & & & \multirow{2}{*}{\multicolumn{4}{|c|}{$\mathrm{B} \times \mathrm{A}-14.21$}} \\
\hline \multicolumn{2}{|l|}{$\mathrm{B} \times \mathrm{A}$} & \multicolumn{3}{|c|}{$\mathrm{B} \times \mathrm{A}-16.73$} & \multicolumn{4}{|c|}{$\mathrm{B} \times \mathrm{A}-5.58$} & & & & \\
\hline
\end{tabular}

$\mathrm{N}_{1}-80 \mathrm{~kg} \mathrm{~N} \mathrm{ha}^{-1} ; \mathrm{N}_{2}-160 \mathrm{~kg} \mathrm{~N} \mathrm{ha}^{-1} ; \mathrm{Ti}_{1}-$ Tytanit $0.2 \% ; \mathrm{Ti}_{2}$-Tytanit $1 \%$.

Table 4. The content of soluble sugars in Festulolium braunii $\left(\mathrm{g} \mathrm{kg}^{-1} \mathrm{DM}\right)$.

\begin{tabular}{|c|c|c|c|c|c|c|c|c|c|c|c|c|}
\hline \multirow{3}{*}{ Treatment } & \multicolumn{4}{|c|}{$\begin{array}{c}2015 \\
\text { (1st Year) }\end{array}$} & \multicolumn{4}{|c|}{$\begin{array}{c}2016 \\
\text { (2nd Year) }\end{array}$} & \multicolumn{4}{|c|}{$\begin{array}{c}2017 \\
\text { (3rd Year) }\end{array}$} \\
\hline & \multicolumn{4}{|c|}{ Cuts } & \multicolumn{4}{|c|}{ Cuts } & \multicolumn{4}{|c|}{ Cuts } \\
\hline & I & II & III & Mean & I & II & III & Mean & I & II & III & Mean \\
\hline Control object & 88.51 & 91.02 & 100.3 & 93.28 & 90.23 & 88.54 & 98.74 & 92.50 & 82.64 & 85.57 & 84.28 & 84.16 \\
\hline $\mathrm{N}_{1}$ & 92.48 & 95.66 & 99.23 & 95.79 & 89.97 & 102.3 & 96.39 & 96.22 & 92.07 & 93.46 & 92.80 & 93.11 \\
\hline $\mathrm{Ti}_{1}$ & 95.42 & 94.56 & 100.2 & 96.73 & 99.87 & 100.7 & 89.67 & 96.73 & 88.73 & 87.25 & 86.40 & 87.46 \\
\hline $\mathrm{Ti}_{2}$ & 100.4 & 123.0 & 132.3 & 118.6 & 113.6 & 100.3 & 99.07 & 104.3 & 92.91 & 90.25 & 93.46 & 92.21 \\
\hline $\mathrm{N}_{1}+\mathrm{Ti}_{1}$ & 118.9 & 109.9 & 109.7 & 112.8 & 120.7 & 118.9 & 120.5 & 120.3 & 129.4 & 116.7 & 120.5 & 122.2 \\
\hline $\mathrm{N}_{2}+\mathrm{Ti}_{2}$ & 125.4 & 112.3 & 120.9 & 119.5 & 109.6 & 118.8 & 120.0 & 116.1 & 124.1 & 119.3 & 123.4 & 122.3 \\
\hline mean & 102.8 & 102.4 & 107.5 & 104.2 & 103.5 & 104.2 & 104.9 & 105.4 & 100.0 & 97.83 & 99.34 & 99.06 \\
\hline \multicolumn{2}{|c|}{$\mathrm{A} \times \mathrm{B}$-interaction } & \multicolumn{3}{|c|}{$\mathrm{A} \times \mathrm{B}-1.18$} & \multicolumn{4}{|c|}{$\mathrm{A} \times \mathrm{B}-4.95$} & \multicolumn{4}{|c|}{$\mathrm{A} \times \mathrm{B}-2.20$} \\
\hline \multicolumn{2}{|l|}{$\mathrm{B} \times \mathrm{A}$} & \multicolumn{2}{|c|}{$\mathrm{B} \times \mathrm{A}-1.51$} & & \multicolumn{4}{|c|}{$\mathrm{B} \times \mathrm{A}-6.32$} & \multicolumn{4}{|c|}{$\mathrm{B} \times \mathrm{A}-2.80$} \\
\hline
\end{tabular}

$\mathrm{N}_{1}-80 \mathrm{~kg} \mathrm{~N} \mathrm{ha}^{-1} ; \mathrm{N}_{2}-160 \mathrm{~kg} \mathrm{~N} \mathrm{ha}^{-1} ; \mathrm{Ti}_{1}-$ Tytanit $0.2 \%$; $\mathrm{Ti}_{2}$-Tytanit $\%$; ns-no significant difference.

According to Ciepiela et al. [39], in addition to nutrient content, the forage value is also determined by the sugar-protein ratio. The value of this indicator should not be less than 0.4 . In the biomass of Festulolium braunii, the sugar-protein ratio ranged from 0.709 to 1.53 (Table 5). In the first year, the highest ratio was in control plants. In the other growing seasons, for plants treated with ammonium nitrate at the amount of $80 \mathrm{~kg} \mathrm{ha}^{-1}$ in combination with the Tytanit foliar application at a concentration of $0.2 \%$, the ratio was 1.29 and 1.00 , respectively. The statistical analysis indicated that the treatment did not have a significant impact on the value of this parameter. In the research of Sosnowski [7], 
the sugar-protein ratio in the biomass of Festulolium braunii treated with NPK fertilizers in combination with soil conditioners was much lower, with 0.51 .

Table 5. The sugar-protein ratio in Festulolium braunii dry matter.

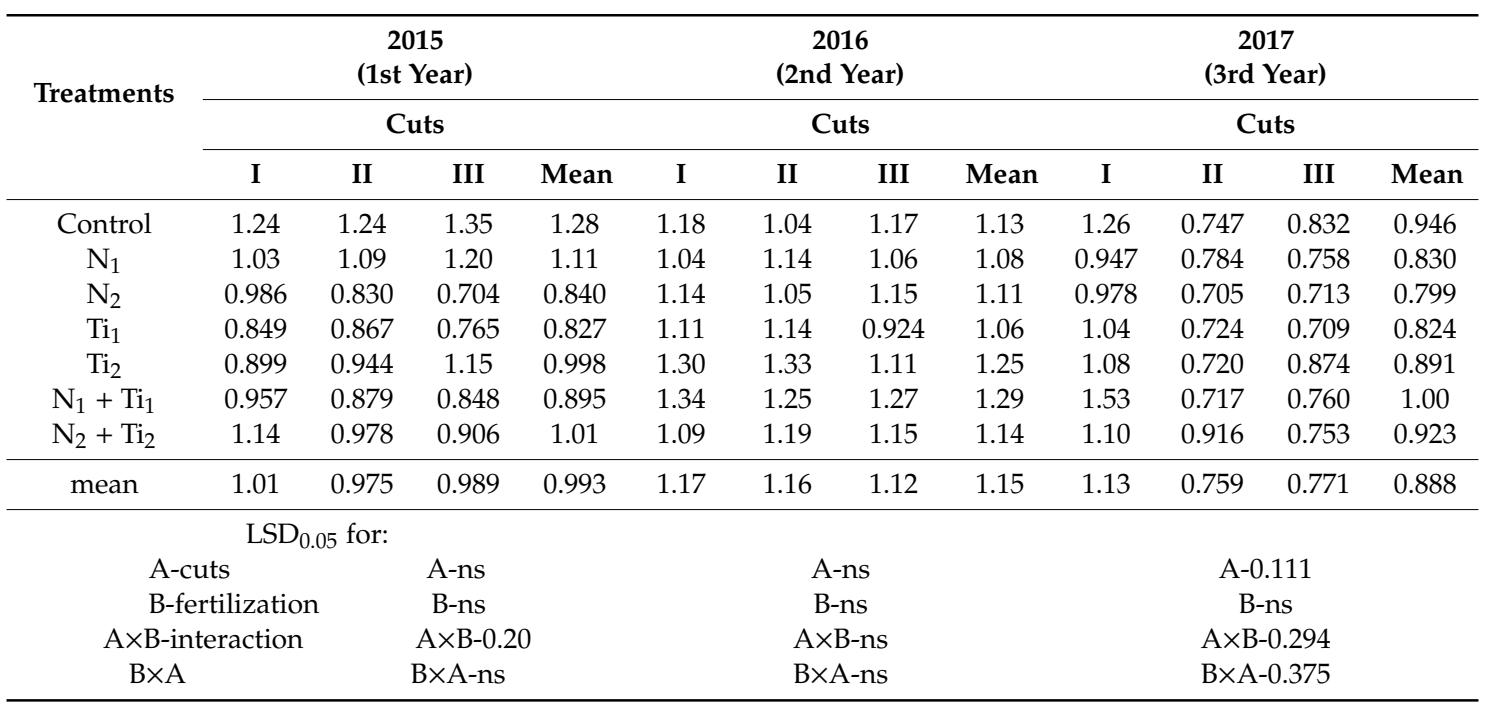

$\mathrm{N}_{1}-80 \mathrm{~kg} \mathrm{~N} \mathrm{ha}^{-1} ; \mathrm{N}_{2}-160 \mathrm{~kg} \mathrm{~N} \mathrm{ha}^{-1} ; \mathrm{Ti}_{1}-$ Tytanit $0.2 \%$; $\mathrm{Ti}_{2}-$ Tytanit $1 \%$; ns-not significant difference.

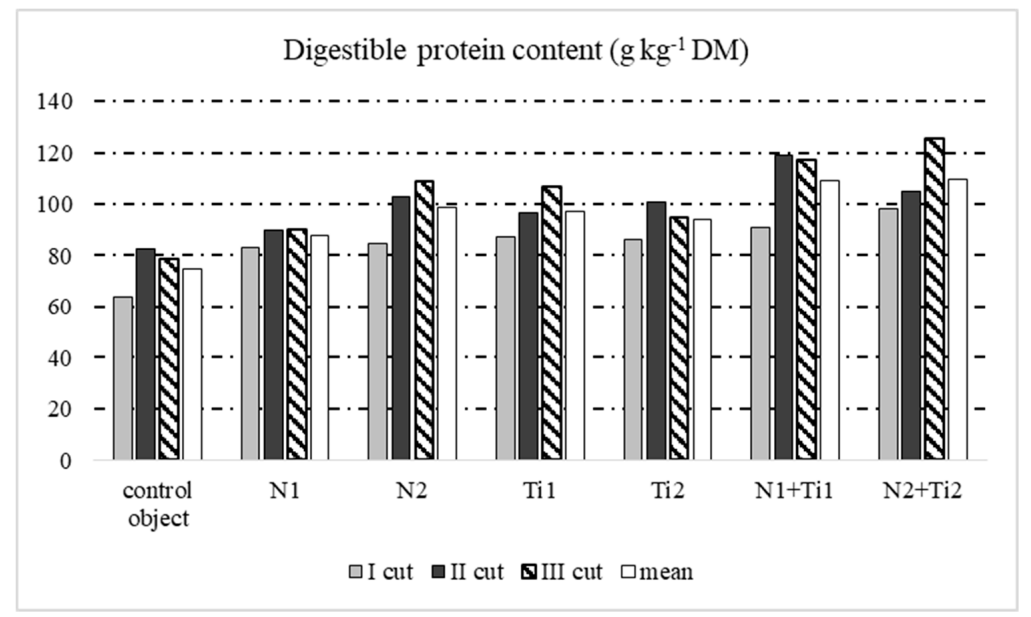

Figure 2. Average digestible protein content in Festulolium braunii across cuts $\left(\mathrm{g} \mathrm{kg}^{-1} \mathrm{DM}\right) . \mathrm{N}_{1}-80 \mathrm{~kg} \mathrm{~N}^{-1}$; $\mathrm{N}_{2}-160 \mathrm{~kg} \mathrm{~N} \mathrm{ha}^{-1}$; $\mathrm{Ti}_{1}-$ Tytanit $0.2 \%$; $\mathrm{Ti}_{2}-$ Tytanit $1 \% . \mathrm{LSD}_{0.05}$ for: A-2.31 (cuts); B-4.49 (treatment); A×B-6.10; $\mathrm{B} \times \mathrm{A}-7.78$ (interaction).

\section{Conclusions}

1. Across all growing seasons, the largest biomass yield of Festulolium braunii was on plots treated with mineral nitrogen at a dose of $160 \mathrm{~kg} \mathrm{ha}^{-1}$ in combination with $1 \%$ Tytanit foliar application. The yield was 40 to $75 \%$ higher than that on control.

2. Tytanit foliar application with a concentration of $1 \%$ increased the yield of plants compared to traditional mineral nitrogen treatment.

3. Mineral nitrogen treatment in combination with Tytanit application positively affected the concentration of protein in the grass.

4. In the first and second years of the experiment, a single Tytanit application with a concentration of $1 \%$ increased the content of soluble sugars in Festulolium braunii, compared to grass treated with nitrogen. 
Author Contributions: E.M., K.J., P.K. and M.G. have equally contributed to this article. All authors have read and agreed to the published version of the manuscript.

Funding: The results of the research carried out under the research theme No. 40/B/20 were financed from the science grant granted by the Ministry of Science and Higher Education.

Conflicts of Interest: The authors declare no conflict of interest.

\section{References}

1. Domański, P.; Joks, W. Festulolium varieties-Effects of biological progres. Zesz. Nauk. ATR Bydgoszcz. 220 Rolnictwo. 1999, 44, 88-93. (In Polish)

2. Oertel, C.; Matzk, F. Introgression of crown rust resistance from Festuca spp. into Lolium multiflorum. Plant Breed. 1999, 118, 491-496. [CrossRef]

3. Rzeźnik, A.; Goliński, P. Achievements in hybrid breeding $\times$ Festulolium. Grassl. Sci. Pol. 2013, 16, 79-98. (In Polish)

4. Humphreys, M.W.; Thomas, H.; Harper, J.; Morgan, G.; James, A.; Ghamari-Zare, A.; Thomas, H. Dissecting drought-And cold tolerance traits in the Lolium-Festuca complex by introgression mapping. N. Phytolog. 1997, 137, 55-60. [CrossRef]

5. Borowiecki, J. Review of work on Festulolium braunii (K. Richter) A. Camus. Pam. Put. 2005, 140, 15-23. (In Polish)

6. Boller, B.; Posselt, U.K.; Veronesi, F. (Eds.) Fodder Crops and Amenity Grasses; Springer: New York, NY, USA, 2010; p. 523.

7. Sosnowski, J. The value of production. energy and food of Festulolium braunii (K. Richt.) A. Camus microbiologically and mineral supplied. Fragm. Agron. 2012, 29, 115-122.

8. Østrem, L.; Volden, B.; Larsen, A. Morphology. dry matter yield and phenological characters at different maturity stages of Festulolium compared with other grass species. Acta Agric. Scand. 2013, 63, 531-542.

9. Gutmane, I.; Adamovics, A. Influence of nitrogen fertilization rates on Festulolium and Lolium $\times$ boucheanum forage yield and persistency. Grassl. Sci. Eur. 2009, 14, 336-338.

10. Mengel, K.; Kirkby, E.A.; Kosegarten, H.; Appel, T. Nitrogen. In Principles of Plant Nutrition; Mengel, K., Kirkby, E.A., Kosegarten, H., Appel, T., Eds.; Springer: Dordrecht, The Netherlands, 2001.

11. Kocon, A.; Grenda, A. The effect of titanite on photosynthesis. Yield and nutrient uptake by rapeseed plants. Adv. Agric. Sci. Probl. 2004, 502, 135-140. (In Polish)

12. Janas, R.; Grzesik, M. The usefulness of biological compounds in organic farming production of promedical plants. J. Res. Appl. Agric. Eng. 2011, 53, 152-157.

13. Ciepiela, G.A. Content of structural and nonstructural carbohydrates and lignin in Dactylis glomerata L. and Festulolium braunii (K. Richt.) A. Camus supplied by biostimulator Kelpak SL and nitrogen. Nauka Przyr. Technol. 2014, 8, 2. (In Polish)

14. Jankowski, K.; Truba, M.; Malinowska, E.; Wiśniewska-Kadżajan, B. The effect of soil conditioners and weather on lawn appearance. J. Ecol. Eng. 2019, 20, 44-52. [CrossRef]

15. Jankowski, K.; Ciepiela, G.A.; Jodełka, J.; Kolczarek, R. Turf Areas; Wydawnictwo Uniwersytetu Przyrodniczo-Humanistycznego w Siedlcach: AP Siedlce, Poland, 2005. (In Polish)

16. Holter, J.A.; Reid, J.T. Relationship between the concentrations of crude protein and apparently digestible protein in forages. J. Anim. Sci. 1959, 18, 1339-1349. [CrossRef]

17. Skowera, B.; Puła, J. Pluviometric extreme conditions in spring season in Poland in the years 1971-2000. Acta Agroph. 2004, 3, 171-177. (In Polish)

18. StatSoft Inc. Statistica (Data Analysis Software System); Version 10; StatSoft: Tulsa, OK, USA, 2011. Available online: www.statsoft.com (accessed on 30 March 2020).

19. Shangguan, Z.P.; Shao, M.A.; Dyckmans, J. Nitrogen nutrition and water stress effects on leaf photosynthetic gas exchange and water use efficiency in winter wheat. Environ. Exp. Bot. 2000, 44, 141-149. [CrossRef]

20. Olszewska, M. Leaf greenness (Spad) and yield of Festulolium braunii (K. Richt.) A. Camus grown in mixtures with legumes depending on multiple nitrogen rates. Pol. J. Nat. 2008, 23, 310-325. [CrossRef]

21. Mastalerczuk, G.; Borawska-Jarmułowicz, B.; Kalaji, H.M.; Dabrowski, P.; Paderewski, J. Gas-exchange parameters and morphological features of Festulolium (Festulolium braunii K. Richter, A. Camus) in response to nitrogen dosage. Phytosynthetica 2017, 55, 20-30. [CrossRef]

22. Staniak, M. Yielding and nutritional value of Festulolium braunii variety Felopa depending on the date of harvesting the first swath. I. Yield and selected elements of its structure. Pam. Put. 2004, 137, 117-131. (in Polish). 
23. Pais, I. The biological importance of titanium. J. Plant. Nutr. 1983, 6, 3-131. [CrossRef]

24. Malinowska, E.; Kalembasa, S. The yield and content of Ti, Fe, Mn, $\mathrm{Cu}$ in celery leaves (Apium Graveolens, L. var. dulce Mill. Pers.) as a result of Tytanit application. Acta Sci. Pol. Hortorum Cultus 2012, 11, 69-80.

25. Kalembasa, S.; Malinowska, E.; Kalembasa, D.; Symanowicz, B. Effect of foliar fertilization with Tytanit on the content of selected macroelements and sodium in celery. J. Elem. 2014, 683-696. [CrossRef]

26. Murawska, B.; Gabrowska, M.; Spychaj-Fabisiak, E.; Wszelaczyńska, E.; Chmielewski, J. Production and environmental aspects of the application of biostimulators Asahi SL, Kelpak SL and stimulator Tytanit with limited doses of nitrogen. Environ. Prot. Nat. Res. 2017, 28, 10-15. [CrossRef]

27. Brzóska, F. Quality of roughage and their use in animal nutrition. Production of roughage for ruminants. In Proceedings of the Naukowej Konferencji, Puławy, Poland, 8-9 May 2007; Institute of Soil Science and Plant Cultivation: Puławy, Poland, 2007; pp. 63-70. (In Polish)

28. Ciepiela, G.A.; Godlewska, A. Changes in protein compounds and monosacharides in select grass species following application of a seaweed extract. Pol. J. Environ. Stud. 2014, 23, 35-41.

29. Fagerberg, B. The quantitative effect of weather on growth and nutritional value of grass leys. In Proceedings of the 16th EGF Meeting Grassland and Land Use Systems, Grado, Italy, 15-19 September 1996; pp. 83-86.

30. Łyszczarz, R. Influence of harvest date on selected features of two varieties of cocksfoot. Biuletyn IHAR 2003, 225, 139-149. (In Polish)

31. Tonn, B.; Bienvenu, C.; Isselstein, J. Assessing quantity and quality of grazed forage on multi-species swards. In The Role of Grasslands in a Green Future, Proceedings of the 17th Symposium of the European Grassland Federation, Akureyri, Iceland, 23-26 June 2013; Helgadóttir, Á., Hopkins, A., Eds.; Agricultural University of Iceland: Reykjavik, Iceland, 2013; Volume 18, pp. 82-84.

32. Godlewska, A.; Ciepiela, G.A. Assessment of the effect of various biostimulants on Medicago $x$ varia T. Martyn yielding and content of selected organic components. Appl. Ecol. Environ. Res. 2018, 16, 5571-5581. [CrossRef]

33. Buraczewski, S. Animal nutrition and feed science. In Physiological and Biochemical Grounds of Animal Nutrition; Wyd Nauk PWN: Warsaw, Poland, 2004; Volume 1, p. 55. (In Polish)

34. Grzelak, M. The productivity and fodder value of Hay from extensively utilised Noteć River Valley Meadows. Nauka Przyr. Technol. 2010, 4, 1-8.

35. Spychała, W.; Frąckowiak, P.; Adamczyk, F. Influence of extrusion parameters of the screw press prototype on the quality of Camelina seed oil and marc. J. Res. Appl. Agric. Eng. 2011, 56, 110-113.

36. Central Statistical Office in Poland (CSO) 2018. Available online: https://stat.gov.pl/obszary-tematyczne/ rolnictwo-lesnictwo/rolnictwo/rolnictwo-w-2018-roku,3,15.html (accessed on 30 March 2020).

37. Czyż, H.; Jänicke, H.; Kitczak, T.; Bury, M. The usefulness of grass mixtures with Festulolium braunii and Lolium perenne for the renewal of grasslands on mucky organic soil. Water-Environ.-Rural Areas 2015, 15, 17-29. (In Polish)

38. Watts, K.A. Carbohydrates in forage: What is a safe grass? In Proceedings of the 2008 Kentucky Equine Research Conference “Facing Today's Nutritional Challenges, Lexington, Kentucky, 14-16 April 2008.

39. Ciepiela, G.A.; Jankowski, J.; Jodełka, J. Evaluation of yield and fodder value of mixtures of meadow clover with brome Biul. Nauk. 1998, 1, 31-38. (In Polish)

(C) 2020 by the authors. Licensee MDPI, Basel, Switzerland. This article is an open access article distributed under the terms and conditions of the Creative Commons Attribution (CC BY) license (http://creativecommons.org/licenses/by/4.0/). 